\title{
Amylin receptor: a common pathophysiological target in Alzheimer's disease and diabetes mellitus
}

\author{
Wen Fu, Aarti Patel and Jack H. Jhamandas* \\ Division of Neurology, Department of Medicine, Centre for Neuroscience, University of Alberta, Edmonton, AB, Canada
}

Edited by:

Fernanda Laezza, University of Texas

Medical Branch, USA

\section{Reviewed by:}

Vadim Fraifeld, Ben Gurion University

of the Negev, Israel

Filippo Tempia, University of Turin,

Italy

\section{*Correspondence:}

Jack H. Jhamandas, Division of Neurology, Department of Medicine, Centre for Neuroscience, University of Alberta, 530 Heritage Medical

Research Centre, Edmonton, AB T6G 2S2, Canada

e-mail: jack.jhamandas@ualberta.ca
Amylin (islet amyloid polypeptide) and amyloid-beta $(A \beta)$ protein, which are deposited within pancreatic islets of diabetics and brains of Alzheimer's patients respectively, share many biophysical and physiological properties. Emerging evidence indicates that the amylin receptor is a putative target receptor for the actions of human amylin and $A \beta$ in the brain. The amylin receptor consists of the calcitonin receptor dimerized with a receptor activitymodifying protein and is widely distributed within central nervous system. Both amylin and $A \beta$ directly activate this $G$ protein-coupled receptor and trigger multiple common intracellular signal transduction pathways that can culminate in apoptotic cell death. Moreover, amylin receptor antagonists can block both the biological and neurotoxic effects of human amylin and $A \beta$. Amylin receptors thus appear to be involved in the pathophysiology of Alzheimer's disease and diabetes, and could serve as a molecular link between the two conditions that are associated epidemiologically.

\section{Keywords: amyloid-beta protein, amylin, amylin receptor, Alzheimer's disease, type-2 diabetes mellitus}

\section{INTRODUCTION}

Both Alzheimer's disease (AD) and type-2 diabetes mellitus (T2DM) are chronic, age-related diseases that share common clinical and biochemical features (Selkoe, 1997; Hoppener et al., 2000; Götz et al., 2009; Wolfson et al., 2009; Tacutu et al., 2010). In addition to epidemiological links between the two diseases (Luchsinger, 2010), insulin-resistant T2DM has been identified as a risk factor for $\mathrm{AD}$ (Craft, 2007). Dysregulation of insulin and IGF-1 (insulin growth factor-1) receptors has been observed in $\mathrm{AD}$ patient brains (Moloney et al., 2010). Impairment of these receptors contributes to increased amyloid-beta $(\mathrm{A} \beta)$ protein aggregation, subsequent synaptic loss, and cognitive impairment (Zhao et al., 2009). T2DM and AD are pathologically characterized by presence of insoluble protein aggregates resulting in formation and deposition of amylin in $\mathrm{T} 2 \mathrm{DM}$ and $\mathrm{A} \beta$ in $\mathrm{AD}$ respectively (Westermark et al., 2011; Abedini and Schmidt, 2013). Amylin or islet amyloid polypeptide (IAPP) is a 37 -amino acid peptide first isolated from amyloid-rich pancreatic extracts of type-2 diabetic patients (Cooper et al., 1987). This misfolded protein forms elongated fibrils with spines consisting of many-stranded $\beta$ sheets and enters the amyloid state (Eisenberg and Jucker, 2012). Amylin is also deposited in human brains in T2DM with dementia and AD patients (Jackson et al., 2013). Both amylin and A $\beta$ directly activate amylin receptors, and the biological effects of these two peptides and their neurotoxic actions can be blocked with specific amylin receptor antagonists (Jhamandas and MacTavish, 2004; Jhamandas et al., 2011). These observations have raised further questions concerning the relationship, at a molecular level, between these two different common clinical conditions and the role that the amylin receptor may play as a common pathological link.

\section{AMYLIN RECEPTORS}

Amylin receptors consist of heterodimerized complexes of the calcitonin receptor (CTR) interacting with one of receptor activitymodifying proteins (RAMPs). CTR is a seven transmembranedomain Class B G protein-coupled receptor. The RAMP is a single-domain protein, and not a receptor itself, with three currently known subtypes named RAMP ${ }_{1-3}$. These RAMPs can heterodimerize with CTR to form a subset of amylin receptors $\left(\mathrm{AMY}_{1-3}\right)$ or in combination with calcitonin receptor-like receptor (CLR) form either calcitonin gene-related peptide (CGRP) or adrenomedullin receptors (Hay and Poyner, 2013). The physiological roles ascribed to amylin are mediated via the amylin receptors (Muff et al., 1999). Distribution of amylin and its receptors is fairly widespread in the brain. The most investigated of amylin functions in the brain relate to control of energy homeostasis and body fluid balance through amylin receptors (Lutz, 2012). In rat, the amylin neural circuit includes the area postrema, a structure devoid of the blood brain barrier, the nucleus of the solitary tract, the lateral parabrachial nucleus, and the central nucleus of the amygdala (Roth et al., 2009). In postpartum rats, amylin levels are significantly elevated in the preoptic nuclei suggesting that this peptide is also involved in maternal physiological functions (Dobolyi, 2009). However, its role in cognitive function is incompletely understood in spite of the localization of this peptide in many areas related to memory and learning. At present, there is no information available on age-related changes in the expression of amylin or its receptors in the brain.

\section{A $\beta$ AND ALZHEIMER'S DISEASE}

The amyloid plaque is one of core pathological hallmarks in $\mathrm{AD}$ (Hardy, 2006; Ballard et al., 2011). A $\beta$ is a 40- or 42-amino acid 
peptide cleaved from a larger precursor, amyloid precursor protein (APP), by the actions of $\beta$ - and $\gamma$-secretases. $A \beta$ can form monomers, oligomers, or fibrils. Small soluble oligomers of $A \beta$ are deemed to be more toxic than mature fibrils (Ballard et al., 2011). AD is a complex neurodegenerative disease caused by multiple dysregulated neurobiological networks and cellular functions, neuronal, and memory loss. It is clear that soluble oligomeric $A \beta$ plays a key role in the pathogenesis of $\mathrm{AD}$, although as a therapeutic target in this condition, it has posed significant challenges, and as yet, is of unproven benefit.

\section{AMYLIN AND TYPE-2 DIABETES}

Amylin is co-secreted with insulin by pancreatic beta-cells but is greatly decreased in diabetic individuals following food intake. It has the propensity to form membrane permeant toxic oligomers and aggregate into fibrils in much the same way as $A \beta$. These toxic amylin oligomers contribute to pancreatic beta-cell loss in T2DM (Haataja et al., 2008). The effects of amylin on glucose metabolism and food intake are mediated by the peripheral and central mechanisms (Young, 2005). Amylin concentration is only $1-2 \%$ that of insulin and concurrently increases with insulin after glucose stimulation. It inhibits glucagon release and influences insulin secretion in a concentration-dependent manner (Akesson et al., 2003). Amylin also inhibits gastric emptying in a manner similar to glucagon-like peptide-1 (GLP1) and decreases food intake via central autonomic mechanisms (Rushing et al., 2000). Although many of amylin functions are still not fully understood, there are two plausible physiological roles of amylin that are of particular interest. The first relates to its function as an auto- or paracrine molecule in the islets of Langerhans, and the other is its role as a neurohormone with effects on the central nervous system (CNS) (Westermark et al., 2011). The amylin fibrillogenicity is species dependent. Although there is only a six amino acid difference between human and rat amylin, human amylin, but not rat, is amyloidogenic and demonstrates neurotoxic properties (Lim et al., 2008).

\section{AMYLIN AND A $\beta$}

Although there is no sequence homology between $A \beta$ and human amylin, both aggregate and form amyloid fibrils. In this process, they share the same important features which include sequencespecific aggregation with oligomeric intermediates as precursors to the aggregated state and the physical state of inclusion bodies. The amyloid fibrils are typically unbranched, variable in length, polymorphic, and form crossed $\beta$-sheet structures (Mitraki, 2010; Abedini and Schmidt, 2013). The amyloid plaque formation could be a dynamic process between protein monomers, oligomers, and fibrils. Amyloid fibrils can be an integral part of normal cellular physiology and serve as storage reservoirs for peptide hormones within secretory granules (Maji et al., 2009). Although A $\beta$ or amylin insoluble fibrils may play some physiological/pathophysiological roles, it is the soluble oligomeric intermediates that are believed to represent the primary toxic species of amyloids (Hardy and Selkoe, 2002). Many soluble oligomers from different proteins (including $A \beta$, amylin, prion protein, alpha-synuclein) display a common conformation-dependent structure that is unique to soluble oligomers regardless of sequence. The oligomer toxicity is inhibited by oligomer-specific antibodies, which suggests that different types of soluble amyloid oligomers have a common structure and share a common mechanism of toxicity (Kayed et al., 2003). Interestingly, human amylin shows strikingly similar neurotoxicity profiles with A $\beta$ (May et al., 1993; Lim et al., 2008, 2010). Amylin receptor antagonists, AC187 or AC253, attenuate or block $A \beta$ - and amylin-induced neurotoxicity, potassium channel activity, and activation of pro-apoptotic genes (Jhamandas et al., 2003, 2011; Jhamandas and MacTavish, 2004). Downregulation of amylin receptor gene expression using siRNA attenuates the oligomerized $A \beta$-induced toxicity (Jhamandas et al., 2011). Moreover, in AD transgenic model mice (TgCRND8) which over-express APP, amylin receptor expression in the brain was up-regulated in an age-dependent manner within specific brain regions that also demonstrated an increased amyloid burden (Jhamandas et al., 2011). A $\beta$, in a manner identical to human amylin, can directly activate AMY3 to raise cyclic adenosine monophosphate (cAMP), increase intracellular calcium, and PKA and MAPK phosphorylation (Fu et al., 2012). Furthermore, AC253 acting via AMY3 receptors, can re-establish the long-term potentiation (LTP) in hippocampus of AD mice (TgCRND8) (Kimura et al., 2012). Thus, many of the effects of $A \beta$, at a cellular level, appear to be expressed via the amylin receptor and such observations support the presence of a direct interaction between oligomer $\mathrm{A} \beta$ and amylin receptors.

\section{INSULIN, IDE, IGF-1 AND 2, AND INSULIN RECEPTORS IN DIABETES AND ALZHEIMER'S DISEASE}

Recently, based on evidence of shared pathophysiology between $\mathrm{AD}$ and $\mathrm{T} 2 \mathrm{DM}, \mathrm{AD}$ has been proposed to represent "Type 3 diabetes" (Steen et al., 2005). Several candidate proteins have been proposed to bridge the pathophysiological link between the two conditions. The major mechanism through which T2DM may influence $\mathrm{AD}$ includes central insulin resistance, which leads to reduced sensitivity to insulin in the brain, resulting in hyperinsulinemia, impaired insulin receptor (IR) signaling, and glucose toxicity (Freude et al., 2009; Han and Li, 2010). T2DM mediated hyperinsulinemic/hypoglycemic episodes may produce long-term changes in brain vasculature, cellular toxicity including inflammation and oxidative stress, alternations in $A \beta$ levels, tau phosphorylation, neurodegeneration, and cognitive impairment, thus facilitating AD onset. It is clear that insulin and IGF-1 have intense effects in the CNS, acting as neuromodulators to influence release and uptake of neurotransmitters, energy homeostasis, neuronal survival, as well as learning and memory (Bosco et al., 2011). There is a decrease in insulin mRNA and protein levels (Steen et al., 2005) and a marked disturbance of IR and IGF-1R signaling in the CNS of AD patients (Frölich et al., 1998). Post-mortem examination of brains from patients with $\mathrm{AD}$ revealed substantial downregulation of IR, IGF-1R, and insulin receptor substrate (IRS) proteins (Squire, 1986), that correlate with the severity and progression of neurodegenerative changes in this condition (Frölich et al., 1998). Insulin resistance has been postulated to interfere with $\mathrm{A} \beta$ catabolism and clearance in $\mathrm{AD}$ pathogenesis (Qiu and Folstein, 2006). Impairment in IGF- 1 is linked to $A \beta$ pathology and IGF- 1 increases $\mathrm{A} \beta$ clearance from brain in AD animal models (Carro et al., 2006). IDE is the chief enzyme that degrades excess insulin and other 
substrates, including A $\beta$ (Farris et al., 2003). The imbalance of the substrates could affect the IDE-induced degradation process, and in the process influence the pathogenesis of $\mathrm{AD}$ or $\mathrm{T} 2 \mathrm{DM}$. Increasing the amount of insulin appears to both stimulate $A \beta$ secretion and also inhibit the IDE enzymatic degradation of extracellular $A \beta$, thus resulting in increased $A \beta$ neurotoxicity (Qiu and Folstein, 2006). Additionally, IDE knockout mice experience decreased $A \beta$ degradation, hyperinsulinemia, and hyperglycemia (Farris et al., 2003).

In summary, amyloid formation is a fundamental process observed in many protein misfolding diseases including $\mathrm{AD}$ and T2DM. Increasing evidence indicates that the intermediate oligomers from different proteins form common conformationdependent structures that play primary pathological roles in neurodegenerative conditions. One common target for the soluble oligomers $A \beta$ and human amylin is the amylin receptor. Figure 1 summarizes our perspective on the commonality of structurefunctional relationships between the two proteins. Activation of the amylin receptor by the two peptides can modulate activity of individual neurons at a cellular and synaptic level, but more chronic exposure to these peptides results in activation of signal transduction pathways that culminate in apoptotic cell death. Currently, the treatment of $\mathrm{AD}$ remains a serious and important public health concern. Beyond symptomatic treatment, there is as yet no effective intervention for AD. Targeting amylin receptors using amylin receptor antagonists to block the deleterious effects of $\mathrm{A} \beta$ and human amylin could represent a novel therapeutic

\section{REFERENCES}

Abedini, A., and Schmidt, A. M. (2013). Mechanisms of islet amyloidosis toxicity in type 2 diabetes. FEBS Lett. 587, 1119-1127. doi:10.1016/j. febslet.2013.01.017

Akesson, B., Panagiotidis, G., Westermark, P., and Lundquist, I. (2003). Islet amyloid polypeptide inhibits glucagon release and exerts a dual action on insulin release from isolated islets. Regul. Pept. 111, 55-60. doi:10.1016/S0167-0115(02) 00252-5

Ballard, C., Gauthier, S., Corbett, A., Brayne, C., Aarsland, D., and Jones, E. (2011). Alzheimer's disease. Lancet 377, 1019-1031. doi:10.1016/ S0140-6736(10)61349-9

Bosco, D., Fava, A., Plastino, M., Montalcini, T., and Pujia, A. (2011). Possible implications of insulin resistance and glucose metabolism in Alzheimer's disease pathogenesis. J. Cell. Mol. Med. 15, 1807-1821. doi: 10.1111/j.1582-4934.2011.01318.x

Carro, E., Trejo, J. L., Gerber, A., Loetscher, H., Torrado, J., Metzger, F., et al. (2006). Therapeutic actions of insulin-like growth factor I on APP/PS2 mice with severe brain amyloidosis. Neurobiol. Aging 27, 1250-1257. doi:10.1016/j. neurobiolaging.2005.06.015
Cooper, G. J., Willis, A. C., Clark, A., Turner, R. C., Sim, R. B., and Reid, K. B. (1987). Purification and characterization of a peptide from amyloid-rich pancreases of type 2 diabetic patients. Proc. Natl. Acad. Sci. U.S.A. 84, 8628-8632. doi:10. 1073/pnas.84.23.8628

Craft, S. (2007). Insulin resistance and Alzheimer's disease pathogenesis: potential mechanisms and implications for treatment. Curr. Alzheimer Res. 4, 147-152. doi:10. 2174/156720507780362137

Dobolyi, A. (2009). Central amylin expression and its induction in rat dams. J. Neurochem. 111, 1490-1500. doi:10.1111/j.14714159.2009.06422.x

Eisenberg, D., and Jucker, M. (2012). The amyloid state of proteins in human diseases. Cell 148, 1188-1203. doi:10.1016/j.cell.2012.02.022

Farris, W., Mansourian, S., Chang, Y., Lindsley, L., Eckman, E. A., Frosch, M. P., et al. (2003). Insulindegrading enzyme regulates the levels of insulin, amyloid betaprotein, and the beta-amyloid precursor protein intracellular domain in vivo. Proc. Natl. Acad. Sci. U.S.A. 100, 4162-4167. doi:10.1073/pnas. 0230450100

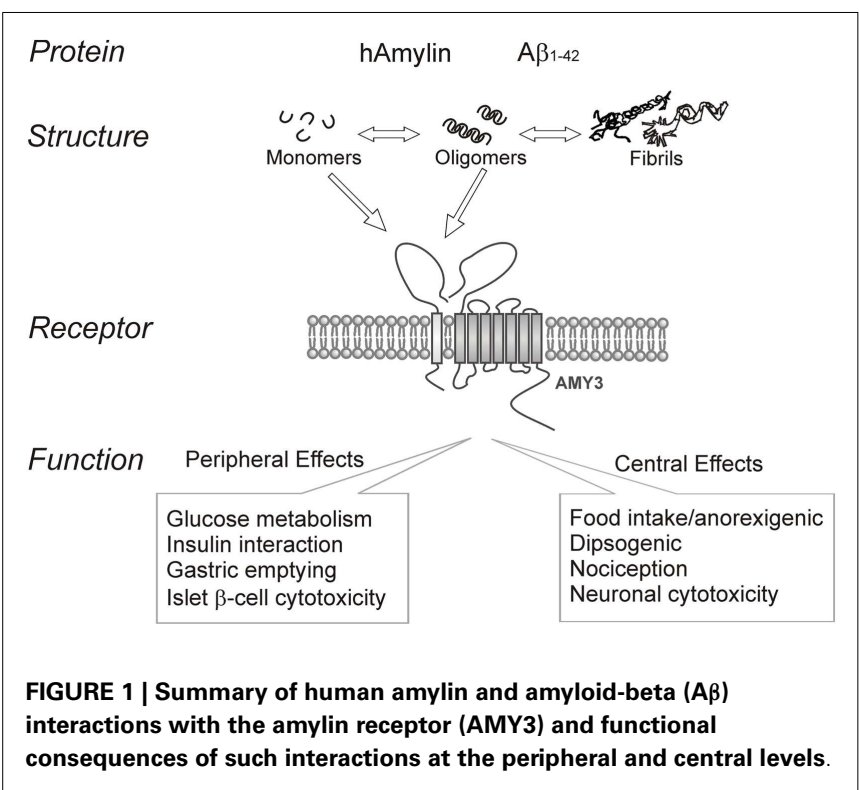

approach to treating $\mathrm{AD}$ and $\mathrm{T} 2 \mathrm{DM}$, conditions that are linked epidemiologically and apparently also at a molecular level.

\section{ACKNOWLEDGMENTS}

Supported by research funding from the Canadian Institutes of Health Research (MOP 93601).
Freude, S., Schilbach, K., and Schubert, M. (2009). The role of IGF1 receptor and insulin receptor signaling for the pathogenesis of Alzheimer's disease: from model organisms to human disease. Curr. Alzheimer Res. 6, 213-223. doi:10. 2174/156720509788486527

Frölich, L., Blum-Degen, D., Bernstein, H. G., Engelsberger, S., Humrich, J., Laufer, S., et al. (1998). Brain insulin and insulin receptors in aging and sporadic Alzheimer's disease. J. Neural Transm. 105, 423-438. doi: 10.1007/s007020050068

Fu, W., Ruangkittisakul, A., MacTavish, D., Shi, J. Y., Ballanyi, K., and Jhamandas, J. H. (2012). A $\beta$ peptide directly activates amylin-3 receptor subtype by triggering multiple intracellular signaling pathways. J. Biol. Chem. 287, 18820-18830. doi:10. 1074/jbc.M111.331181

Götz, J., Ittner, L. M., and Lim, Y. A. (2009). Common features between diabetes mellitus and Alzheimer's disease. Cell. Mol. Life Sci. 66, 1321-1325. doi:10.1007/s00018-009-9070-1

Haataja, L., Gurlo, T., Huang, C. J., and Butler, P. C. (2008). Islet amyloid in type 2 diabetes, and the toxic oligomer hypothesis. Endocr. Rev. 29, 303-316. doi:10.1210/er.2007-0037
Han, W., and Li, C. (2010). Linking type 2 diabetes and Alzheimer's disease. Proc. Natl. Acad. Sci. U.S.A. 107, 6557-6558. doi:10.1073/pnas. 1002555107

Hardy, J. (2006). Has the amyloid cascade hypothesis for Alzheimer's disease been proved? Curr. Alzheimer Res. 3, 71-73. doi:10.2174/156720506775697098

Hardy, J., and Selkoe, D. J. (2002). The amyloid hypothesis of Alzheimer's disease: progress and problems on the road to therapeutics. Science 297, 353-356. doi:10.1126/science. 1072994

Hay, D., and Poyner, D. R. (2013). Calcitonin receptors. IUPHAR Database (IUPHAR-DB). Available at: http: //www.iuphar-db.org/DATABASE/ FamilyMenuForward?familyId=11 (accessed June 20, 2013; last modified on 06/03/2013).

Hoppener, J. W., Ahren, B., and Lips, C. J. (2000). Islet amyloid and type 2 diabetes mellitus. N. Engl. J. Med. 343, 411-419. doi:10.1056/ NEJM200008103430607

Jackson, K., Barisone, G. A., Diaz, E., Jin, L. W., Decarli, C., and Despa, F. (2013). Amylin deposition in the brain: a second amyloid in Alzheimer disease? Ann. Neurol. doi: 10.1002/ana.23956 
Jhamandas, J. H., Harris, K. H., Cho, C., Fu, W., and MacTavish, D. (2003). Human amylin actions on rat cholinergic basal forebrain neurons: antagonism of beta-amyloid effects. J. Neurophysiol. 89, 2923-2930. doi: 10.1152/jn.01138.2002

Jhamandas, J. H., Li, Z., Westaway, D., Yang, J., Jassar, S., and MacTavish, D. (2011). Actions of $\beta$ amyloid protein on human neurons are expressed through the amylin receptor. Am. J. Pathol. 178, 140-149. doi:10.1016/j.ajpath.2010. 11.022

Jhamandas, J. H., and MacTavish, D. (2004). Antagonist of the amylin receptor blocks beta-amyloid toxicity in rat cholinergic basal forebrain neurons. J. Neurosci. 24, 5579-5584. doi:10.1523/JNEUROSCI.1051-04. 2004

Kayed, R., Head, E., Thompson, J. L., McIntire, T. M., Milton, S. C., Cotman, C. W., et al. (2003). Common structure of soluble amyloid oligomers implies common mechanism of pathogenesis. Science 300, 486-489. doi:10.1126/science. 1079469

Kimura, R., MacTavish, D., Yang, J., Westaway, D., and Jhamandas, J. H. (2012). Beta amyloidinduced depression of hippocampal long-term potentiation is mediated through the amylin receptor. $\mathrm{J}$. Neurosci. 32, 17401-17406. doi:10.1523/ JNEUROSCI.3028-12.2012

Lim, Y. A., Ittner, L. M., Lim, Y. L., and Götz, J. (2008). Human but not rat amylin shares neurotoxic properties with Abeta42 in long-term hippocampal and cortical cultures. FEBS Lett. 582, 2188-2194. doi:10. 1016/j.febslet

Lim, Y. A., Rhein, V., Baysang, G., Meier, F., Poljak, A., Raftery, M. J., et al. (2010). Abeta and human amylin share a common toxicity pathway via mitochondrial dysfunction. Proteomics 10, 1621-1633. doi:10.1002/ pmic. 200900651

Luchsinger, J. A. (2010). Type 2 diabetes, related conditions, in relation and dementia: an opportunity for prevention? J. Alzheimers Dis. 20, 723-736. doi:10.3233/JAD2010-091687

Lutz, T. A. (2012). Control of energy homeostasis by amylin. Cell. Mol. Life Sci. 69, 1947-1965. doi:10.1007/ s00018-011-0905-1

Maji, S. K., Perrin, M. H., Sawaya, M. R., Jessberger, S., Vadodaria, K., Rissman, R. A., et al. (2009). Functional amyloids as natural storage of peptide hormones in pituitary secretory granules. Science 325, 328-332. doi:10.1126/science. 1173155

May, P. C., Boggs, L. N., and Fuson, K. S. (1993). Neurotoxicity of human amylin in rat primary hippocampal cultures: similarity to Alzheimer's disease amyloid-beta neurotoxicity. J. Neurochem. 61, 2330-2333. doi:10. 1111/j.1471-4159.1993.tb07480.x

Mitraki, A. (2010). Protein aggregation from inclusion bodies to amyloid and biomaterials. $A d v$. Protein Chem. Struct. Biol. 79, 89-125. doi:10.1016/S18761623(10)79003-9

Moloney, A. M., Griffin, R. J., Timmons, S., O'Connor, R., Ravid, R., and O'Neill, C. (2010). Defects in IGF-1 receptor, insulin receptor and IRS-1/2 in Alzheimer's disease indicate possible resistance to IGF-1 and insulin signalling. Neurobiol. Aging 31, 224-243. doi:10.1016/j. neurobiolaging.2008.04.002

Muff, R., Bühlmann, N., Fischer, J. A., and Born, W. (1999). An amylin receptor is revealed following cotransfection of a calcitonin receptor with receptor activity modifying proteins-1 or -3. Endocrinology
140,2924-2927. doi:10.1210/en.140. 6.2924

Qiu, W. Q., and Folstein, M. F. (2006). Insulin, insulin-degrading enzyme and amyloid-beta peptide in Alzheimer's disease: review and hypothesis. Neurobiol. Aging 27, 190-198. doi:10. 1016/j.neurobiolaging.2005.01.004

Roth, J. D., Maier, H., Chen, S., and Roland, B. L. (2009). Implications of amylin receptor agonism: integrated neurohormonal mechanisms and therapeutic applications. Arch. Neurol. 66, 306-310. doi:10.1001/archneurol. 2008.581

Rushing, P. A., Hagan, M. M., Seeley, R. J., Lutz, T. A., and Woods, S. C. (2000). Amylin: a novel action in the brain to reduce body weight. Endocrinology 141, 850-853. doi:10. 1210/en.141.2.850

Selkoe, D. J. (1997). Alzheimer's disease: genotypes, phenotypes, and treatments. Science 275, 630-631. doi:10. 1126/science. 275.5300 .630

Squire, L. R. (1986). Mechanisms of memory. Science 232, 1612-1619. doi:10.1126/science.3086978

Steen, E., Terry, B. M., Rivera, E. J., Cannon, J. L., Neely, T. R., Tavares, R. et al. (2005). Impaired insulin and insulin-like growth factor expression and signaling mechanisms in Alzheimer's disease - is this type 3 diabetes? J. Alzheimers Dis. 7 , 63-80.

Tacutu, R., Budovsky, A., and Fraifeld V. E. (2010). The NetAge database: a compendium of networks for longevity, age-related diseases and associated processes. Biogerontology 11, 513-522. doi:10.1007/s10522010-9265-8

Westermark, P., Andersson, A., and Westermark, G. T. (2011). Islet amyloid polypeptide, islet amyloid, and diabetes mellitus. Physiol. Rev.
91, 795-826. doi:10.1152/physrev. 00042.2009

Wolfson, M., Budovsky, A., Tacutu, R., and Fraifeld, V. (2009). The signaling hubs at the crossroad of longevity and age-related disease networks. Int. J. Biochem. Cell Biol. 41, 516-520. doi:10.1016/j.biocel. 2008.08.026

Young, A. (2005). Receptor pharmacology. Adv. Pharmacol. 52, 47-65. doi: 10.1016/S1054-3589(05)52003-9

Zhao, W. Q., Lacor, P. N., Chen, H., Lambert, M. P., Quon, M. J., Krafft, G. A., et al. (2009). Insulin receptor dysfunction impairs cellular clearance of neurotoxic oligomeric A $\beta$. J. Biol. Chem. 284, 18742-18753. doi: 10.1074/jbc.M109.011015

Conflict of Interest Statement: The authors declare that the research was conducted in the absence of any commercial or financial relationships that could be construed as a potential conflict of interest.

Received: 26 June 2013; paper pending published: 17 July 2013; accepted: 03 August 2013; published online: 15 August 2013.

Citation: $F u$ W, Patel $A$ and Jhamandas JH (2013) Amylin receptor: a common pathophysiological target in Alzheimer's disease and diabetes mellitus. Front. Aging Neurosci. 5:42. doi: 10.3389/fnagi.2013.00042 Copyright (C) 2013 Fu, Patel and Jhamandas. This is an open-access article distributed under the terms of the Creative Commons Attribution License (CC BY). The use, distribution or reproduction in other forums is permitted, provided the original author(s) or licensor are credited and that the original publication in this journal is cited, in accordance with accepted academic practice. No use, distribution or reproduction is permitted which does not comply with these terms. 